\title{
Decision Support System Performance-Based Evaluation of Village Government using AHP and TOPSIS Methods: Secang Sub-district of Magelang Regency as a Case Study
}

\author{
Vickky Listyaningsih \\ SMKN 2, Magelang, Central Java, 56115, Indonesia \\ E-mail: vlistyaningsih@gmail.com \\ Ema Utami \\ Magister of Informatics Engineering, Universitas Amikom Yogyakarta, Yogyakarta, 55281, Indonesia \\ E-mail: emma@nrar.net
}

Received: 22 April 2017; Accepted: 13 September 2017; Published: 08 April 2018

\begin{abstract}
The increasing of village grants provider growth opportunities for villages every year. The Reliable performance of village governance is the main factor that determines the development of a village. In Secang, there are still many rural governance performances that are not optimal yet, therefore we need a system of performance evaluation of the village government. Decision support systems with a combination of AHP and TOPSIS models can be used to help evaluating performance village Government. AHP method is used to perform the weighting of the criteria and TOPSIS methods to make a ranking system of the performance evaluation of village government. AHP was chosen because it has many advantages of computation weighting while TOPSIS was efficient and able to measure the relative performance in a simple mathematical form. One advantage of the system that was built is the dynamic nature of the assessment criteria used for the calculation process, with menus for assessment criteria period the user can add or reduce the assessment criteria in accordance with the requirements or regulations. Output of DSS Village Government Performance Evaluation is village government performance ratings that can be used as a consideration in determining rewards and assistance to the village from the sub-district. From the test results on ranking and prototype, $86.67 \%$ of users agree that the prototype can be implemented and used to evaluate the performance of village government in the Secang sub-district.
\end{abstract}

Index Terms-Decision support system, AHP, TOPSIS, performance evaluation, village governance.

\section{INTRODUCTION}

The government has allocated large numbers of budget for the empowerment of villages in Indonesia. This village grant increases every year. In 2015, the government disbursed 9.01 trillion rupiah in which every village collects 750 million rupiah. In 2016 budget, the village grant budget was allocated for 20.7 trillion rupiah and in 2017 it is planned to be 89 trillion rupiah. The fund is intended to resolve the various issues in each village, to increase the economic activities and reduce the level of urbanization [1].

Based on the fact, it can be concluded that every village has a chance to develop. The development of a village is determined by three factors: the village administration, territorial administration and people management [2]. Out of the three factors above, the village administration is the main driver for managing the region and developing rural communities. A reliable performance of village governance is the main factor that determine the development of a village. In Secang subdistrict, there are still many rural governance performance that are not optimal, therefore we need a system of performance evaluation of village government. Such evaluation may be taken into consideration in the development of policies and villages mapping conducted by sub-districts administration [3].

Akbar and Perrin stated that the local governments need a support from the society, therefore the government must demonstrate his government's performance by measuring and managing their performance [4]. To facilitate the evaluating process and to ensure the professionalism in conducting the evaluation, it is necessary for the Secang sub-district to apply performance the village government evaluation based on technology and information. By using the Decision Support System (DSS), the evaluation process can be rapid, measurable and consistent in decision making moreover it can also be accountable.

The method that used by the author is a combination of AHP and TOPSIS Methods. The AHP method is used to weight the criteria then proceed to the TOPSIS method 
process for ranking the evaluation of village governance performance. The parameters used in village governance performance are employee presence attendance data, village gathering data, village governance administrative data, community development activities, information technology and computer usage data, village action plan (RKADes) and RPJM data, budgets data and village development implementation reports. The Implementation of system using MySQL and Framework Code Igniter. In System testing uses test ranking and user prototype testing.

The remainder of this paper is organized as follows: Section 2 describes related work. Section 3 explains the research method used. Section 4 describes how the AHP and TOPSIS methods can solve the problems in this paper and section 5 describes conclusions and future work are given in the final section.

\section{RELATED WORK}

Decision support system is a computer-based system that produces a wide range of decisions alternatives that assist the management in dealing with various structured or unstructured problems using data and models [5]. The method involves a lot of decision-making criteria which usually described as Multi Criteria Decision Making (MCDM) method. According to Olson in its development, MCDM methods that are widely used and developed are Simple Multi attribute Rating Theory (SMART), Analytical Hierarchy Process (AHP), Technique for Order Preference by Similarity to Ideal Solution (TOPSIS), ELimination and Choice Expressing Reality (ELECTRE), Preference Ranking Organization Method for Enrichment Evaluations (PROMETHEE) [6]. Das, et.al did research about Multi Criterion Decision Making using Intuitionistic Fuzzy Rough Set on Two Universal Sets [7] and Goodridge performed a sensitivity analysis using the Simple Additive Weighting (SAW) MCDM method [8]. In his paper, the SAW method is extended to include an objective function which makes it easy to analyze the influence of specific changes in certain criteria values thus making easy to perform sensitivity analysis.

AHP is one of the MCDM method that is very good in modeling expert opinion in decision support systems. In developing the model, AHP perform pairwise comparisons variables that become a decisive factor in the decision-making process [9], but the AHP method is not effective when used in cases with high number of criteria and alternatives [10]. Triantaphyllou and Mann using AHP to help the decision makers in the field of engineering [11]. Wei et al. using AHP to build decision support systems in the selection of the Enterprise Resource Planning (ERP) system [12].

There are several studies conducted using TOPSIS method such as by Ataei using TOPSIS and fuzzy TOPSIS to build a decision support system for plant layout design [13]. Athawale and Chakraborty using TOPSIS to build a decision support system in evaluating the CNC machines specifications and costs [14].
Saharuddin using TOPSIS because it has the advantages of simplicity in concept and easy to understand, efficient computing and has the capability to measure the relative performance of the alternatives in the decision of a simple mathematical form [15]. The disadvantage of TOPSIS method is that it must determine and calculate the weights beforehand. Abdulah \& Otheman considers entropy weights for sub-criteria in interval type-2 fuzzy TOPSIS method, to propose a new objective weight for subcriteria in interval type-2 fuzzy TOPSIS [16]. Hamdani, et.al used technique for order preference by similarity to ideal solution (TOPSIS) method to update weight and this method is effectively performed in decision-making which has different parameters and weights of each DM to support group decision [17]. Hybrid models performed to determine the distance of the weight of each of the methods used in each of the criteria using AHP, fuzzy AHP, TOPSIS, Grey theory, fuzzy TOPSIS, GreyTOPSIS [18]. Grey model is used to improve the model of MCDM. The combination of grey models with MCDM models uses SAW, TOPSIS and grey relational analysis (GRA) [19]

Prasetyo tried to use several of the MCDM models which are AHP, PROMETHEE, ELECTRE and TOPSIS, then the results of each model is analyzed in its weights sensitivity and data changes sensitivity [20]. Based on the results of the analysis, TOPSIS was chosen as a suitable model for performance appraisal for SKPD. Because the sensitivity of weight and sensitivity of the data is good. As for the weighting, AHP is used. Sabaghi, M., \& Mascle, C. make a decision support system for selecting and evaluating several car models with criteria using Design of Experiment (DOE) with full factorial method and TOPSIS models [21]. Arbelia \& Paryanta using AHP and TOPSIS as a decision support system in determining advancement for employees [22].

Based on the data above, the formulation of the problem of this research is how the decision support system with a combination of AHP and TOPSIS models can help to evaluate the government's performance in villages of Secang sub-district of Magelang regency.

\section{RESEARCH METHODS}

The stages and workflow of this research can be seen in figure 1 .

The method of this research is using analysis, design (design), implementation and evaluation. The collection of data by interview and observation of the village data such as employee presence attendance data, village gathering data, administrative data of village governance, community development activities data of the village, information technology and computer usage data, the action plan of the village (RKADes) and RPJM data, the data of budgets and reports of village development implementation. The data was then processed into the assessment criteria. Having established the criteria, the data can be weighed against the criteria using AHP, after weighting was known, we will rank the performance using TOPSIS method. 


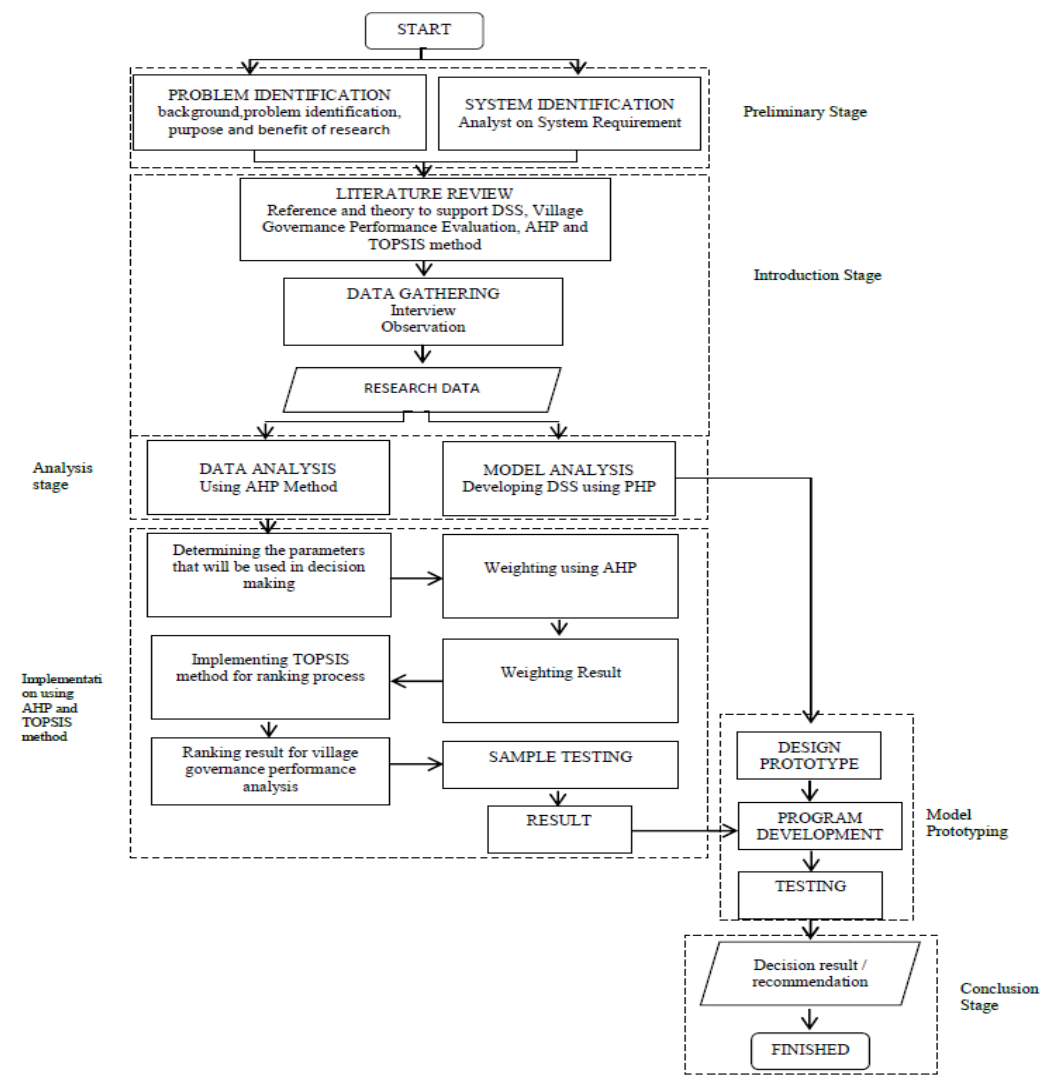

Fig.1. Research Workflow

The stages in AHP model can be described as:

a. Converting the decisions into a hierarchy. Organizing hierarchy starts with defining the top level and continues with criteria and sub criteria

b. Assigning the pairwise comparison matrix. According Kusumadewi, et al pairwise comparison matrix can be constructed by [23]:

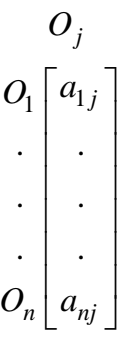

$\mathrm{O}=$ criteria

$\mathrm{n}=$ number of parameters

$\mathrm{w}_{\mathrm{i}}=$ weight of prameter number $i$

$\mathrm{a}_{\mathrm{ij}}=$ comparison of weight between parameter $i$ and parameter $j$

$$
\begin{aligned}
& \begin{array}{llll}
O_{1} & O_{2} \ldots & O_{n}
\end{array} \\
& O_{1}\left[\frac{W_{1}}{W_{1}} \frac{W_{1}}{W_{2}} \ldots \frac{W_{1}}{W_{n}}\right. \\
& O_{2} \frac{W_{2}}{W_{2}} \\
& \cdot \begin{array}{lll}
\cdot & \cdot & \cdot \\
O_{n} & \cdot & \cdot \\
\frac{W_{n}}{W_{n}} & \frac{W_{1}}{W_{n}} & \frac{W_{n}}{W_{n}}
\end{array}
\end{aligned}
$$

c. Normalizing the columns of the pairwise comparison

$$
w i=a i j /\left(\sum_{k=1}^{n} a k j\right)
$$

d. Calculating the sum of the value for every $i$ column

$$
a=\sum_{j} a_{i j}
$$


e. Initial weight for each $i$ parameter comes from dividing each $a$ value with the number of parameter in comparison (n)

$$
w_{i}=\frac{a_{i}}{n}
$$

f. Calculating the Consistency Index (CI)

$$
C I=\frac{\lambda_{m a k s}-^{n}}{n-1}
$$

Where as

$$
\lambda_{\text {maks }}=\frac{1}{n} \sum_{i=1}^{n} \frac{x_{i}}{w_{i}}
$$

g. Calculating Consistency Ratio (CR)

$$
C R=\frac{C I}{R I}
$$

The Random Index (RI) is a CI random value for matrix orders. Consistency that is expected is a near perfect consistency in order to give a valid decision with a consistency value less than or equal to $10 \%$.

TOPSIS based on the concept that the best alternative was selected not only because it has the shortest distance from the positive ideal solution, but it also has the longest distance from the negative ideal solution [24]. According to Zeleny, the concept is widely used in some models of MADM to solve problems in a practical decision because the concept is simple, easy to understand, efficient in computing and has the ability to measure the relative performance of alternatives in the form of a simple mathematical decision [25]. The next stage of decisionmaking with TOPSIS models are as follows:

a. Normalizing $\mathrm{X}_{\mathrm{ij}}$ data into $\mathrm{R}_{\mathrm{ij}}$

$$
R_{i j}=\frac{\left[X_{i j}-\operatorname{Min}\left(X_{i j}\right)\right]}{\left[\operatorname{Max}\left(X_{j}\right)-\operatorname{Min}\left(X_{j}\right)\right]}
$$

b. Multiplying each normalized matrix value with the assigned weight value.

$$
V_{i j}=r_{i j} w_{j} ; j=1,2,3, \ldots n ; i=1,2,3, \ldots m
$$

c. Calculating the positive and negative ideal solution

$$
\begin{aligned}
& \left\{V_{1}^{+}, V_{2}^{+}, V_{3}^{+}, \ldots \ldots V_{n}^{+},\right\}=\left\{\left(\max _{i} V_{i j} \mid i=1, \ldots, m\right)\right\} \\
& \left\{V_{1}^{-}, V_{2}^{-}, V_{3}^{-}, \ldots \ldots V_{n}^{-},\right\}=\left\{\left(\min _{i} V_{i j} \mid i=1, \ldots, m\right)\right\}
\end{aligned}
$$

d. Determining the distance between the positive ideal solution and negative ideal solution.

$$
D_{i}^{+}=\left(\sum_{j=1}^{n}\left(V_{i j}-V_{j}^{+}\right)^{2}\right)^{0.5}
$$

$$
D_{i}^{-}=\left(\sum_{j=1}^{n}\left(V_{i j}-V_{j}^{-}\right)^{2}\right)^{0.5}
$$

e. Calculating the closest ideal distance

$$
C_{i}=\frac{D_{i}^{-}}{D_{i}^{-}-D_{i}^{+}} ; i=1,2,3, \ldots m ; 0<C_{i}<1
$$

Build a ranking by maximizing ration toward $e$ in which the highest value is the best alternative or value.

\section{RESULT AND DISCUSSION}

The first step is to determine the operational criteria that will be used for assessment. After determining the operational criteria, the next stage is AHP.

1. Set priorities by including the criteria pairwise comparison matrix initial weights in Table 1 into the matrix of pairwise using equation (1) and equation (2) as seen in Table 2.

Table 1. Criteria of Operation

\begin{tabular}{|c|c|c|}
\hline $\begin{array}{c}\text { Criteria } \\
\text { Code }\end{array}$ & Criteria Item & $\begin{array}{c}\text { Initial } \\
\text { Weight }\end{array}$ \\
\hline K1 & Staff attendance & 6 \\
\hline K2 & Accomplishment of Musrenbangdes & 1 \\
\hline K3 & Village Governance Administration & 7 \\
\hline K4 & Community Development Activities & 3 \\
\hline K5 & $\begin{array}{c}\text { Information Technology and Computer } \\
\text { Usage }\end{array}$ & 5 \\
\hline K6 & $\begin{array}{c}\text { Punctuality of RPJM dan RKADes } \\
\text { Completion }\end{array}$ & 4 \\
\hline K7 & Financial Implementation & 8 \\
\hline K8 & $\begin{array}{c}\text { Punctuality in Completing the Village } \\
\text { Governance Report of Conduct }\end{array}$ & 2 \\
\hline
\end{tabular}


Table 2. Pairwise Comparison Matrix

\begin{tabular}{|c|c|c|c|c|c|c|c|c|}
\hline Criteria & K1 & K2 & K3 & K4 & K5 & K6 & K7 & K8 \\
\hline K1 & 1 & 6 & 0,857 & 2 & 1,2 & 1,5 & 0,75 & 3 \\
\hline K2 & 0,167 & 1 & 0,142 & 0,333 & 0,2 & 0,25 & 0,125 & 0,5 \\
\hline K3 & 1,167 & 7 & 1 & 2,333 & 1,4 & 1,75 & 0,875 & 3,5 \\
\hline K4 & 0,5 & 3 & 0,429 & 1 & 0,6 & 0,75 & 0,375 & 1,5 \\
\hline K5 & 0,833 & 5 & 0,714 & 1,667 & 1 & 1,25 & 0,625 & 2,5 \\
\hline K6 & 0,667 & 4 & 0,571 & 1,333 & 0,8 & 1 & 0,5 & 2 \\
\hline K7 & 1,333 & 8 & 1,143 & 2,667 & 1,6 & 2 & 1 & 4 \\
\hline K8 & 0,333 & 2 & 0,286 & 0,667 & 0,4 & 0,5 & 0,3 & 1 \\
\hline SUM & 6,0 & 36,0 & 5,143 & 12,0 & 7,2 & 9 & 4,5 & 18 \\
\hline
\end{tabular}

2. Normalizing the pairwise comparison matrix suing equation (3) and determining the sum of every row

in the normalized matrix using equation (4).

Table 3. Normalized Matrix

\begin{tabular}{|c|c|c|c|c|c|c|c|c|c|c|}
\hline & K1 & K2 & K3 & K4 & K5 & K6 & K7 & K8 & SUM & WEIGHT \\
\hline K1 & 0,17 & 0,17 & 0,17 & 0,17 & 0,17 & 0,17 & 0,17 & 0,17 & 1,33 & 0,17 \\
\hline K2 & 0,03 & 0,03 & 0,03 & 0,03 & 0,03 & 0,03 & 0,03 & 0,03 & 0,22 & 0,03 \\
\hline K3 & 0,19 & 0,19 & 0,19 & 0,19 & 0,19 & 0,19 & 0,19 & 0,19 & 1,55 & 0,19 \\
\hline K4 & 0,08 & 0,08 & 0,08 & 0,08 & 0,08 & 0,08 & 0,08 & 0,08 & 0,67 & 0,08 \\
\hline K5 & 0,14 & 0,14 & 0,14 & 0,14 & 0,14 & 0,14 & 0,14 & 0,14 & 1,11 & 0,14 \\
\hline K6 & 0,11 & 0,11 & 0,11 & 0,11 & 0,11 & 0,11 & 0,11 & 0,11 & 0,89 & 0,11 \\
\hline K7 & 0,22 & 0,22 & 0,22 & 0,22 & 0,22 & 0,22 & 0,22 & 0,22 & 1,78 & 0,22 \\
\hline K8 & 0,06 & 0,06 & 0,06 & 0,06 & 0,06 & 0,06 & 0,06 & 0,06 & 0,44 & 0,06 \\
\hline
\end{tabular}

In this stage, equation (5) is used to get the value of $\mathrm{W}_{\mathrm{i}}$ based on the value of $R_{i}$ divided with matrix index.

3. Calculating the matrix summation of every row.
The matrix addition from every row can be determined from the multiplication of weight against the initial matrix comparison which results can be seen in Table 4.

Table 4. Row Summation Matrix

\begin{tabular}{|c|c|c|c|c|c|c|c|c|c|}
\hline Criteria & K1 & K2 & K3 & K4 & K5 & K6 & K7 & K8 & SUM \\
\hline K1 & 0,17 & 1,00 & 0,14 & 0,33 & 0,20 & 0,25 & 0,13 & 0,50 & 2,72 \\
\hline K2 & 0,01 & 0,03 & 0,004 & 0,01 & 0,01 & 0,01 & 0,004 & 0,01 & 0,08 \\
\hline K3 & 0,23 & 1,36 & 0,19 & 0,45 & 0,27 & 0,34 & 0,17 & 0,68 & 3,70 \\
\hline K4 & 0,04 & 0,25 & 0,04 & 0,08 & 0,05 & 0,06 & 0,03 & 0,13 & 0,68 \\
\hline K5 & 0,12 & 0,69 & 0,10 & 0,23 & 0,14 & 0,17 & 0,09 & 0,35 & 1,89 \\
\hline K6 & 0,07 & 0,44 & 0,06 & 0,15 & 0,09 & 0,11 & 0,06 & 0,22 & 1,21 \\
\hline K7 & 0,30 & 1,78 & 0,25 & 0,59 & 0,36 & 0,44 & 0,22 & 0,89 & 4,83 \\
\hline K8 & 0,02 & 0,11 & 0,02 & 0,04 & 0,02 & 0,03 & 0,01 & 0,06 & 0,30 \\
\hline
\end{tabular}

4. Calculating the value of priority vector from pairwise comparison matrix. In this stage, the value of vector priority $\mathrm{V}_{\mathrm{i}}$ is calculated from the value of $\mathrm{a}_{\mathrm{ij}}$ matrix multiplied with $\mathrm{W}_{\mathrm{i}}$ weight as in Table 5.

Table 5. Value of Vector Priority of Pairwise Comparison Matrix

\begin{tabular}{|c|c|c|c|}
\hline CRITERIA & SUM OF ROW & PRIOROTY & RESULT \\
\hline K1 & 2,72 & 0,17 & 2,89 \\
\hline K2 & 0,08 & 0,03 & 0,10 \\
\hline K3 & 3,70 & 0,19 & 3,89 \\
\hline K4 & 0,68 & 0,08 & 0,76 \\
\hline K5 & 1,89 & 0,14 & 2,03 \\
\hline K6 & 1,21 & 0,11 & 1,32 \\
\hline K7 & 4,83 & 0,22 & 5,05 \\
\hline K8 & 0,30 & 0,06 & 0,36 \\
\hline
\end{tabular}


5. Calculating the Consistency Index (CI) using equation (6) lamda max using equation (7) and Consistency Ratio (CR) using equation (8) as follows:

$\begin{array}{cr}\text { SUM OF VALUE RESULT } & 16.40 \\ \text { n (number of criteria) } & 8 \\ \text { lamda max (sum/n) } & 2.05 \\ \text { CI (lamda max-n)/n) } & -0.62 \\ \text { CR }(\text { CI/IR) } & -0.0044\end{array}$

The value of $\mathrm{CR}$ must be $\leq 0.10$, if $\mathrm{CR} \leq 0.10$ then the weight value is acceptable or consistent vice versa. With $\mathrm{CR}=-0.0044$ therefore it can be said that the weight value is acceptable or consistent. This study uses data from 19 villages in TOPSIS method to determine the value of the weight (w) of each criterion using the weights (w) calculated by AHP where the value of the weight (w) have been tested for consistency with the value Consistency Ratio $(\mathrm{CR}) \leq 0.10$.

Stages in TOPSIS as follows:

1. Building the TOPSIS criteria value matrix. TOPSIS criteria value matrix can be seen in Table 6.

Table 6. TOPSIS criteria value matrix

\begin{tabular}{|c|c|c|c|c|c|c|c|c|}
\hline CRITERIA & K1 & K2 & K3 & K4 & K5 & K6 & K7 & K8 \\
\hline D1 & 94 & 2 & 2 & 3 & 2 & 1 & 100 & 1 \\
\hline D2 & 88 & 2 & 2 & 2 & 1 & 1 & 100 & 1 \\
\hline D3 & 90 & 2 & 2 & 3 & 2 & 1 & 100 & 1 \\
\hline D4 & 90 & 2 & 1 & 2 & 1 & 1 & 99,4 & 1 \\
\hline D5 & 87 & 2 & 2 & 2 & 1 & 1 & 100 & 1 \\
\hline D6 & 90 & 2 & 3 & 2 & 2 & 1 & 100 & 1 \\
\hline D7 & 95 & 2 & 3 & 3 & 3 & 1 & 100 & 1 \\
\hline D8 & 92 & 2 & 3 & 3 & 2 & 1 & 100 & 1 \\
\hline D9 & 90 & 2 & 3 & 3 & 2 & 1 & 100 & 1 \\
\hline D10 & 94 & 2 & 3 & 3 & 2 & 1 & 100 & 1 \\
\hline D11 & 95 & 2 & 3 & 3 & 2 & 1 & 100 & 1 \\
\hline D12 & 95 & 2 & 3 & 3 & 2 & 1 & 100 & 1 \\
\hline D13 & 90 & 2 & 1 & 2 & 1 & 1 & 100 & 1 \\
\hline D14 & 95 & 2 & 3 & 3 & 2 & 1 & 100 & 1 \\
\hline D15 & 88 & 2 & 1 & 2 & 1 & 1 & 100 & 1 \\
\hline D16 & 90 & 2 & 2 & 2 & 2 & 1 & 100 & 1 \\
\hline D17 & 92 & 2 & 2 & 2 & 2 & 1 & 100 & 1 \\
\hline D18 & 89 & 2 & 1 & 2 & 1 & 1 & 100 & 1 \\
\hline D19 & 90 & 2 & 1 & 3 & 3 & 1 & 100 & 1 \\
\hline
\end{tabular}

Criteria value matrix on table 6 was calculated from the pairing rating value from each criterion.

2. Normalizing the pairwise comparison matrix. The next step is normalizing the pairwise comparison matrix using equation (9). As an example R11 = $94 / 397.97=0.236$. The normalized matrix can be seen on figure 2 .

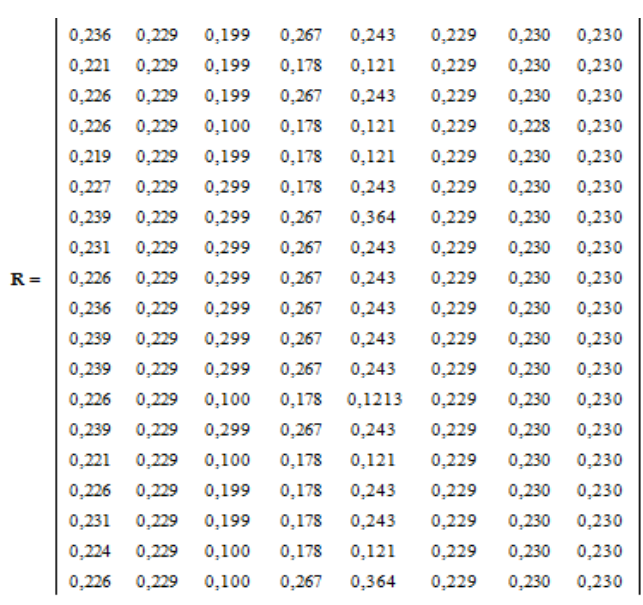

Fig.2. Normalized Matrix

3. Determining the weighted normalized matrix. After the matrix has been normalized, the next step is making a weighted normalized matrix. The weighted normalized decision matrix was calculated from the multiplication of normalized matrix with the preferential weight from $\mathrm{AHP} \mathrm{w}_{\mathrm{i}}=$ $(0.167,0.028,0.194,0.083,0.111,0.222,0.056)$ on figure 3 using equation (10).

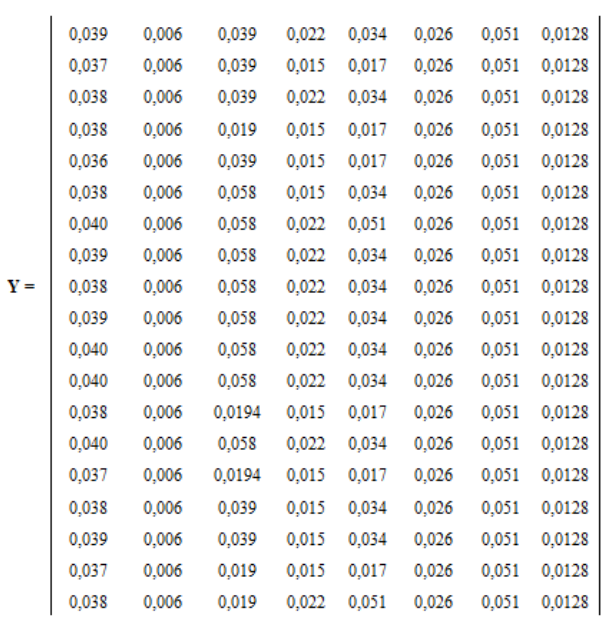

Fig.3. Weighted Normalized Matrix

4. Determining the positive ideal solution and negative ideal solution. The next step is determining the positive ideal solution and negative ideal solution. The positive solution is marked in $\mathrm{A}+$ while the negative is in A-. The equation to find an ideal solution can be seen in equation (11). The total sum of the best performance results in positive ideal solution while negative ideal solution is a total sum of the worst performance using equation (12), results can be seen on Table 7 . 
Table 7. Positive Ideal Solution and Negative Ideal Solution Value

\begin{tabular}{|c|c|}
\hline A+ & A- \\
\hline 0,040 & 0,036 \\
\hline 0,006 & 0,006 \\
\hline 0,058 & 0,019 \\
\hline 0,022 & 0,015 \\
\hline 0,051 & 0,017 \\
\hline 0,026 & 0,026 \\
\hline 0,051 & 0,051 \\
\hline 0,013 & 0,013 \\
\hline
\end{tabular}

5. Calculating the distance value from each alternatives toward the ideal solution. Based on equation (11) and (12), the distance of each alternatives toward the positive ideal solution can be calculated as well as the negative ideal solution which will give the distance toward the ideal solution. Separation measure is a calculation of an alternative to both positive and negative ideal solution. The calculation of both can be seen in equation (13) and (14) while the result can be seen in table 8 .

Table 8 . The value distance from each alternative to the ideal positive solution

\begin{tabular}{|c|c|c|}
\cline { 2 - 3 } \multicolumn{1}{c|}{} & D+ & D- \\
\hline D1 & 0,025655327 & 0,026866766 \\
\hline D2 & 0,039658079 & 0,019354884 \\
\hline D3 & 0,025737233 & 0,026735885 \\
\hline D4 & 0,051881356 & 0,001256386 \\
\hline D5 & 0,039691235 & 0,019350352 \\
\hline D6 & 0,018525054 & 0,04222227 \\
\hline D7 & 0 & 0,051947235 \\
\hline D8 & 0,016889536 & 0,042902696 \\
\hline D9 & 0,016972409 & 0,042869979 \\
\hline D10 & 0,016847947 & 0,042951725 \\
\hline D11 & 0,016842741 & 0,042982339 \\
\hline D12 & 0,016842741 & 0,042982339 \\
\hline D13 & 0,051880453 & 0,001293109 \\
\hline D14 & 0,016842741 & 0,042982339 \\
\hline D15 & 0,051921005 & 0,000518667 \\
\hline D16 & 0,026786566 & 0,025684481 \\
\hline D17 & 0,026734134 & 0,025739052 \\
\hline D18 & 0,051899044 & 0,000891731 \\
\hline D19 & 0,038752481 & 0,034518094 \\
\hline
\end{tabular}

6. Calculating the value of preference for each alternative to determine the ranking of each alternative, there is the need to firstly calculate the preference value of each alternative. The calculation of the value of preference can be seen through the equation (15), as shown in Table 9. At this stage $V_{i}$ values obtained for each village, it can be produced in accordance with the rank order preference value that is owned by the village. If there are villages that have the same score then to find the order of the ranking is based from the total of the value criteria of each village.
Table 9. Village Governance Performance Rank

\begin{tabular}{|c|c|c|c|}
\hline VILLAGE & TOTAL & SCORE & RANK \\
\hline D7 & 220 & 1 & 1 \\
\hline D14 & 222 & 0,7184669 & 2 \\
\hline D12 & 219 & 0,7184669 & 3 \\
\hline D11 & 204 & 0,7184669 & 4 \\
\hline D10 & 220 & 0,7182602 & 5 \\
\hline D8 & 213 & 0,7175296 & 6 \\
\hline D9 & 213 & 0,7163815 & 7 \\
\hline D6 & 202 & 0,6950474 & 8 \\
\hline D3 & 202 & 0,5115327 & 9 \\
\hline D1 & 202 & 0,5095158 & 10 \\
\hline D17 & 203 & 0,4905182 & 11 \\
\hline D16 & 201 & 0,4894982 & 12 \\
\hline D19 & 199 & 0,4711044 & 13 \\
\hline D2 & 188 & 0,3279768 & 14 \\
\hline D5 & 179 & 0,3277411 & 15 \\
\hline D13 & 175 & 0,0243187 & 16 \\
\hline D4 & 188,40 & 0,0236439 & 17 \\
\hline D18 & 187 & 0,0168918 & 18 \\
\hline D15 & 179 & 0,0098907 & 19 \\
\hline & & &
\end{tabular}

At this stage $V_{i}$ values has been obtained for each village, it can be used to rank according to order preference value that of each village. If there are villages that have the same score then to find the order of the ranking is seen from the table in total which is a total of the value criteria of each village, by calculating the sum of net benefit criteria with a deduction based on the cost criteria.

The system design is described in the following use case diagram as shown below in figure 4 .

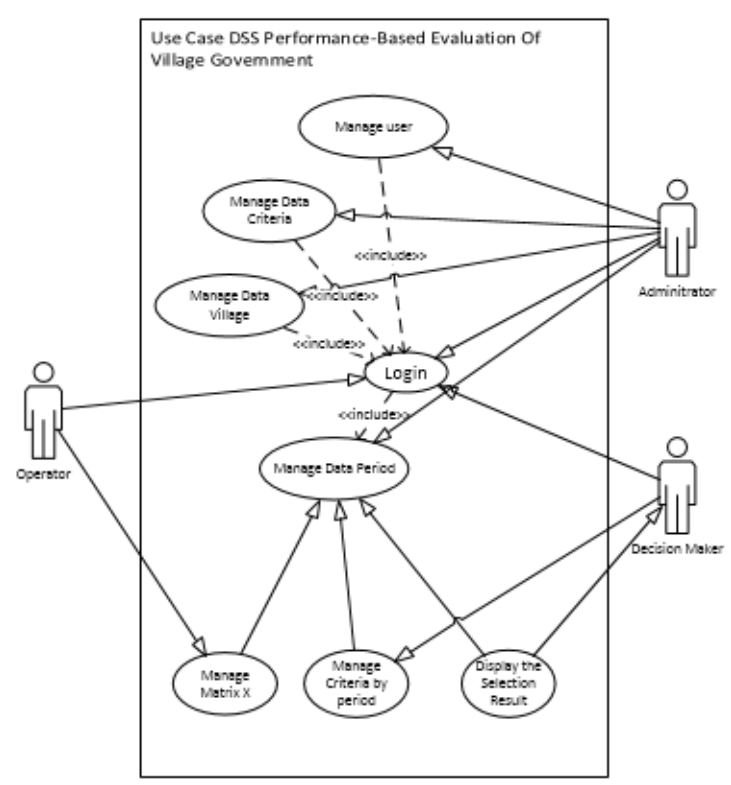

Fig.4. Use Case Diagram for DSS Performance-Based Evaluation of Village Government

Figure 4 shows a conceptual data flow from the decision support system, where there are at least three users of the system. The decision maker in this case is 
sub-district decision maker or Camat who uses the system to rank the performance of the system of village government. Camat has a permission to determine the criteria of each period and gave the initial weight. Administrators have the responsibility of managing the user data, managing the data criteria and processing village's data. While the operator has a responsibility to the availability of data of each period and manage the matrix. Figure 5 shows the class diagram of the decision support system.

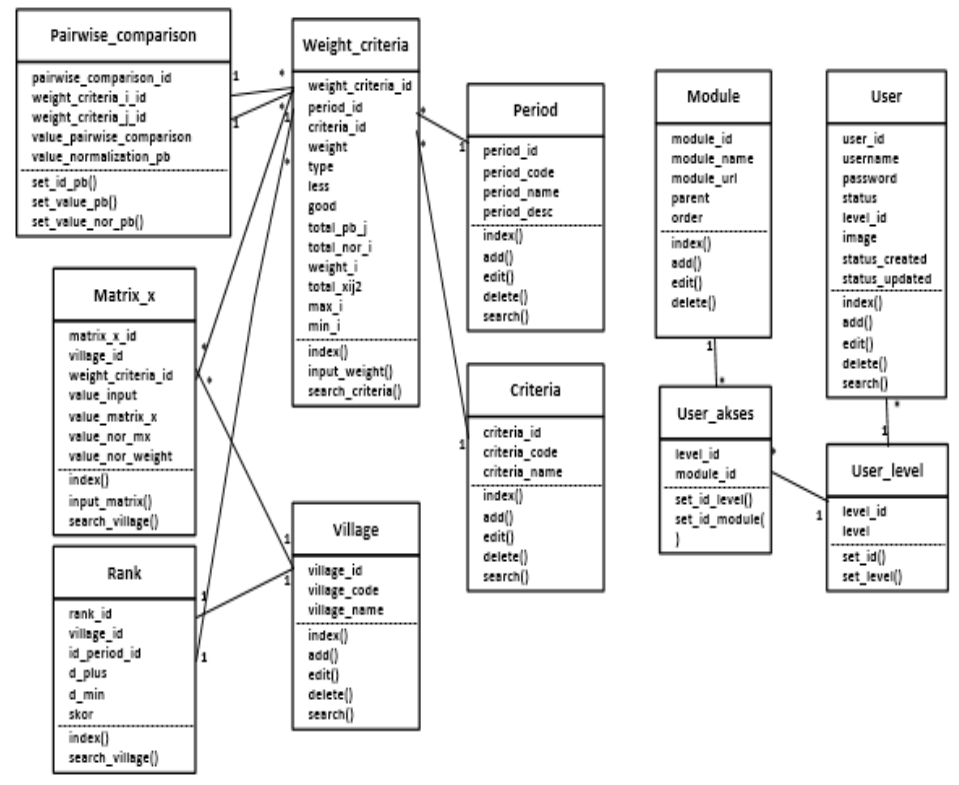

Fig.5. Class Diagram

The design of the system is implemented in the following program as shown below in figure 6 .

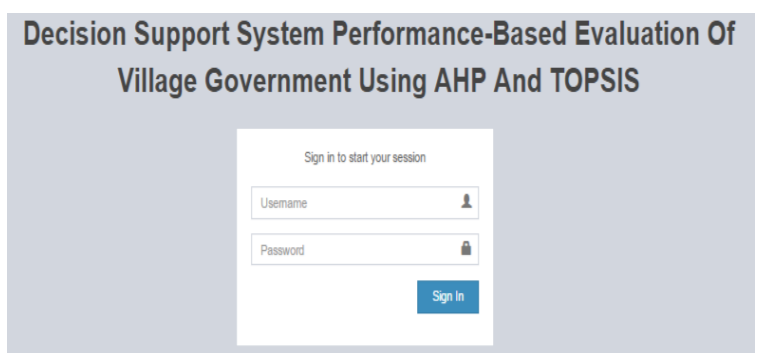

Fig.6. Login page

Figure 6 shows the login page that consists of three user levels, namely the admin, district leader or Camat and facility operators that have different function in accordance with their respective authorities. Figure 7 shows the period page, Camat can manage criterion, the initial weight and also display the results of each period.

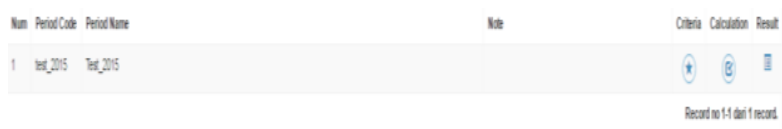

Fig.7. Period Page

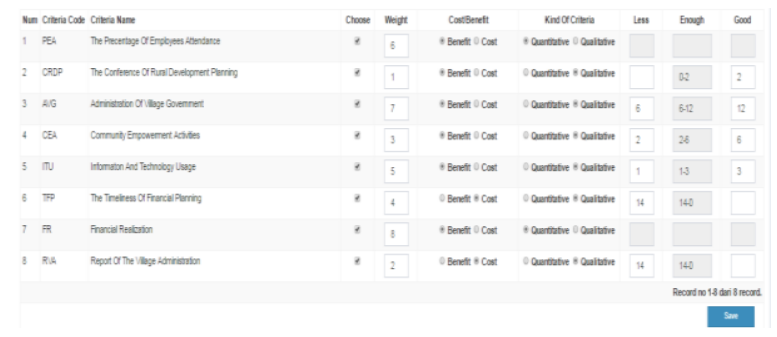

Fig.8. Criteria Assignment and Initial Weighting Page

Figure 8 shows the Criteria Assignment and Initial Weighting Page, Camat can define the criteria to be used in the valuation sector in a particular period, Camat could use the old criteria or add new criteria adapted to the prevailing regulations. After determining the criteria that will be used Camat can also determine the initial weight of each criterion in which the weights will be generated within the pairwise matrix of AHP method. Benefit criteria used to add value and cost to reduce the value. The criteria included consist of two types which are quantitative measurements in form of percentage and qualitative in form of assessment within range of good, sufficient and insufficient.

Figure 9 shows the criteria input pages for each village, where it is the duty of the operator to prepare the data and input it into the system. These data are data collected from each village to the sub-district either in form of administrative data or monitoring result from Secang subdistrict. 


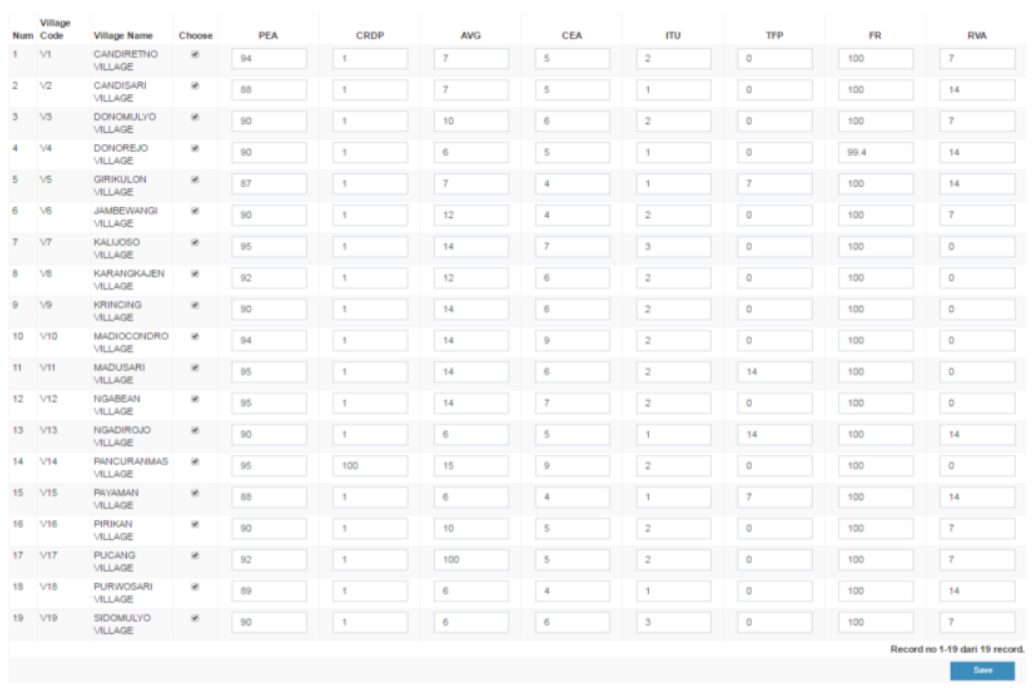

Fig.9. Data Input for each period

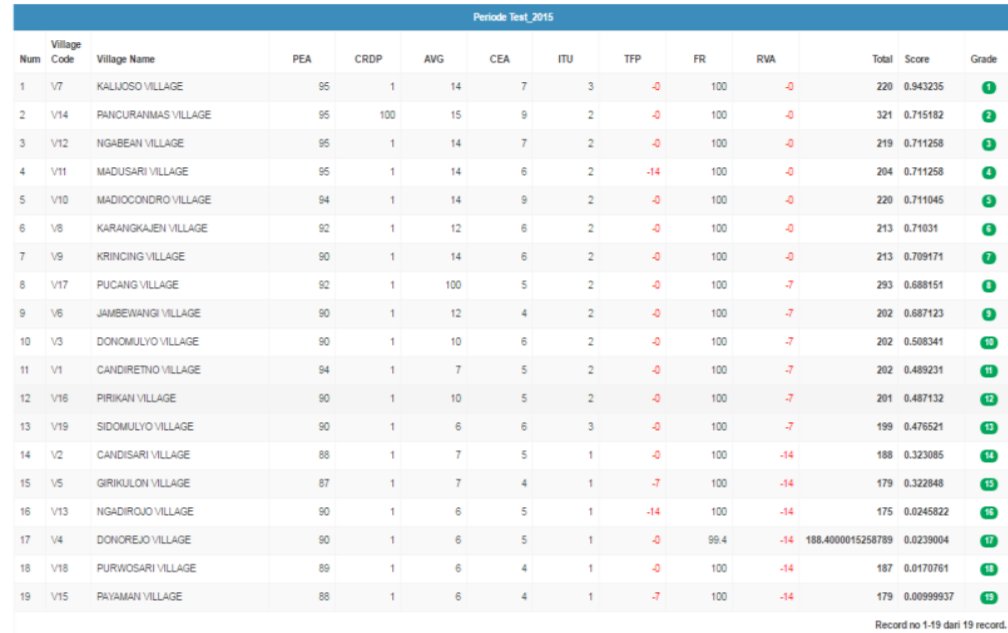

Fig.10. Ranking Page

On the ranking page is shown in figure 10 , we can see the village ranking results complete with the value of each criterion, the score, and the results of the weighting. This is the result of a decision support system of village government performance evaluation that can be used as a basis for policy making in giving rewards and assistance for villages in the sub-district of Secang, Magelang.

Table 10. The Result of DSS Implementation Questionnaire

\begin{tabular}{|c|c|c|c|c|c|c|}
\hline \multirow{2}{*}{ No } & \multirow{2}{*}{ Question } & \multicolumn{5}{|c|}{ Percentage of Response (\%) } \\
\hline & & SA & A & $\mathrm{N}$ & $\mathrm{D}$ & SD \\
\hline 1 & $\begin{array}{l}\text { The implemented prototype can be used to evaluate the } \\
\text { performance of village governance and ranks the village } \\
\text { governance }\end{array}$ & 70 & 20 & 10 & 0 & 0 \\
\hline 2 & $\begin{array}{l}\text { The prototype has criteria that are suitable with the } \\
\text { expected village governance performance evaluation }\end{array}$ & 50 & 40 & 0 & 10 & 0 \\
\hline 3 & The prototype gives you a flexibility to add criteria & 70 & 20 & 0 & 10 & 0 \\
\hline 4 & $\begin{array}{l}\text { The prototype gives you a flexibility to change the weight } \\
\text { for each criteria }\end{array}$ & 70 & 10 & 20 & 0 & 0 \\
\hline 5 & $\begin{array}{l}\text { Every change in weight that you made will results in a } \\
\text { decision that is in accordance with the change in weight }\end{array}$ & 60 & 30 & 0 & 10 & 0 \\
\hline 6 & $\begin{array}{l}\text { The ranking system that is made by the DSS can be used } \\
\text { to determine which village government that performs } \\
\text { good and which one that performs bad. }\end{array}$ & 50 & 30 & 20 & 0 & 0 \\
\hline & TOTAL & 61,67 & 25,00 & 8,33 & 5,00 & 0 \\
\hline
\end{tabular}


Once the systems are made and implemented, testing was next step. Testing is done in two ways. The first way is by comparing the calculation results of TOPSIS phases using both the system and manual. In this way it can be ensured that there is no difference between a manual process and system processes. The next test is by listening to our users through a questionnaire. The questionnaire contains 10 questions and distributed to Camat, sub-district secretary, Head of Governance Section, Head of Village Community Empowerment Section, Head of Public Welfare Section, Head of Security and Order Section and the four District staff. Table 10 shows that $61.67 \%$ of respondents strongly agreed that the DSS prototype used to evaluate the performance of the village administration. $25 \%$ of respondents agree if the prototype DSS is used to evaluate the performance of the village administration. This means that $86.67 \%$ of respondents agreed that the DSS tested prototype can be used to evaluate the performance of the village administration.

\section{CONCLUSION}

Based on the discussion of the results, design, implementation, and testing of the DSS, it can be concluded that the DSS can be applied and can assist in evaluating the performance of the village government. The use of AHP and TOPSIS can provide performance ratings of the village administration. Using the assessment period function will allows the user to change the criteria and weighting for each period of assessment in accordance to the regulatory laws and policies so that the DSS is dynamic. The application of this system requires a strong commitment between the village and the sub-district government for the availability of data in order to be more accurate.

\section{REFERENCES}

[1] http://bisniskeuangan.kompas.com, accessed date October 18,2016

[2] Ministry of Interior Republic of Indonesia, Regulation No 8. 2015 regarding the Evaluation of Village Development

[3] Law No. 32, 2004, article 126 clause (3) regarding the Regional Government

[4] R. Akbar, R. Pilcher, and B. Perrin, "Performance Measurement in Indonesia: the Case of Local Government", Pacific Accounting Review, pp. 262-291, 2012.

[5] R. McLeod, G. Schell, Management Information System, Prentice Hall, 2003

[6] D. L. Olson, "Multi-Criteria Decision Support", In Handbook on Decision Support Systems, Springer Berlin : Heidelberg, 2008.

[7] T. K. Das, D. P. Acharjya, M. R. Patra, Multi Criterion Decision Making using Intuitionistic Fuzzy Rough Set on Two Universal Sets, International Journal of Intelligent Systems and Applications (IJISA), Vol.4, No.4, p. 26-33, 2015.

[8] W. S. Goodridge, Sensitivity Analysis using Simple Additive Weighting Method, International Journal of Intelligent Systems and Applications (IJISA), Vol.5, No.4, p.27-33, 2016.
[9] A. Calabrese, R. Costa, T. Menichini., "Using Fuzzy AHP to manage Intellectual Capital assets: An application to the ICT service industry", Journal Expert Systems with Applications, Vol. 40, No. 9, pp. 3747-3755, 2013.

[10] S. Rouhani, G. Mehdi, J. Mostafa, "Evaluation model of business intelligence for enterprise system using fuzzy TOPSIS", Journal Expert Systems with Applications Vol. 39, No. 3, pp. 3764-3771, 2012.

[11] E. Triantaphyllou, S. H. Mann, "Using the Analytic Hierarchy Process for Decision Making in Engineering Applications: Some Challenges", International Journal of Industrial Engineering: Applications and Practice, Vol. 2, No. 1, pp. 35-44, 1995.

[12] CC. Wei, C. Chien, M. J. Wang, "An AHP-Based Approach to ERP System Selection", Int. J. Production Economics, Vol. 96, pp. 47-62, 2005.

[13] E. Ataei, "Application of TOPSIS and Fuzzy TOPSIS Methods for Plant Layout Design", World Applied Sciences Journal, Vol. 24, No.7, pp. 908-913, 2013.

[14] V. M. Athawale, and S. Chakraborty, "A TOPSIS Method-based Approach to Machine Tool Selection", Proceedings of the 2010 International Conference on Industrial Engineering and Operations Management Dhaka, Bangladesh, January 9-10, 2010.

[15] Saharuddin, "Sistem Pendukung Keputusan Kelompok dengan Metode Topsis dan Borda untuk Penentuan Peringkat Terbaik Sekolah Menengah Atas (SMA) (Studi Kasus: Dinas Pendidikan Pemuda Dan Olahraga Kabupaten Pangkep Sulawesi Selatan)", Thesis, Universitas Gadjah Mada, 2012.

[16] L. Abdullah, and A. Otheman, A New Entropy Weight for Sub-Criteria in Interval Type-2 Fuzzy TOPSIS and Its Application, International Journal of Intelligent Systems and Applications (IJISA), Vol.2, No.3, p.25-33, 2013.

[17] H. Hamdani, R. Wardoyo, K. Mustofa, "A Method of Weight Update in Group Decision-Making to Accommodate the Interests of All the Decision Makers", International Journal of Intelligent Systems and Applications (IJISA), Vol.9, No.8, pp.1-10, 2017.

[18] B. Oztaysi, -A decision model for information technology selection using AHP integrated TOPSIS-Grey: The case of content management systems, KnowledgeBased Syst., vol. 70, pp. 44-54, Nov. 2014.

[19] P. Wang, Z. Zhu, and Y. Wang, -A novel hybrid MCDM model combining the SAW, TOPSIS and GRA methods based on experimental design, Inf. Sci. (Ny)., vol. 345, pp. 27-45, Jun. 2016.

[20] Prasetyo, "Perancangan Sistem Pendukung Keputusan Evaluasi Kinerja Satuan Kerja Perangkat Daerah (Studi Kasus: Pemerintah Daerah Provinsi Sulawesi Barat)", Thesis, Universitas Amikom Yogyakarta, 2016.

[21] M. Sabaghi, and C. Mascle, "Application of DOETOPSIS Technique in Decision-Making Problems", IFAC-Papers OnLine, Vol. 48, No.3, pp. 773-777, 2015.

[22] Arbelia and Paryanta, "Penerapan Metode AHP dan TOPSIS Sebagai Sistem Pendukung Keputusan Dalam Menentukan Kenaikan Jabatan Bagi Karyawan”, Jurnal Ilmiah Go Infotech, Vol. 20, No.1, pp. 9-17, 2014.

[23] S. Kusumadewi, S. Hartati, A. Harjoko, R. Wardoyo, "Fuzzy Multi-Attribute Decision Making (Fuzzy MADM)", Yogyakarta : Graha Ilmu, 2006.

[24] C. L. Hwang, and K. Yoon, "Multiple Attribute Decision Making : Methods and Applications", New York : Springer-Verlag, 1981.

[25] M. Zeleny, "Multiple Criteria Decision Making", New York : McGraw-Hill, 1982. 


\section{Authors' Profiles}

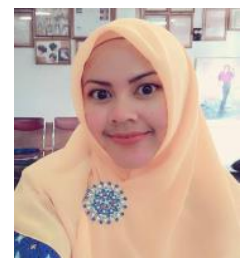

Vickky Listyaningsih was born in Sukoharjo, January 10, 1984. She received the bachelor of computer from Universitas AKI Semarang, Indonesia in 2004. She

4 received the magister of informatics engineering from Universitas Amikom Yogyakarta, Indonesia in 2017. Since 2006 Vickky Listyaningsih, S.Kom, M.Kom has been a teacher of Software Engineering at SMKN 2 Magelang, Indonesia.

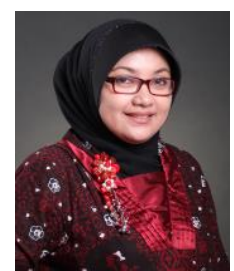

Ema Utami was born in Lampung, on February 21, 1975. She received bachelor, master and doctoral degrees in computer science from Universitas Gadjah Mada, Yogyakarta, Indonesia in 1997, 2002 and 2010 respectively. Since 1998 she has been a lecturer and researcher in Universitas Amikom Yogyakarta. Since 2010 she has been a vice director in magister of informatics engineering in Universitas Amikom Yogyakarta. She has wrote more than 15 computer science related books and published nationally. Prof. Dr. Ema Utami, S.Si, M.Kom is member of several professional societies such as IEEE, IAENG, MASTEL and also as secretary general of national professional societies, IndoCEISS. Her current research interest area are natural language processing, intelligent systems, computer algorithms and database programming.

How to cite this paper: Vickky Listyaningsih, Ema Utami, "Decision Support System Performance-Based Evaluation of Village Government using AHP and TOPSIS Methods: Secang Sub-district of Magelang Regency as a Case Study", International Journal of Intelligent Systems and Applications(IJISA), Vol.10, No.4, pp.18-28, 2018. DOI: 10.5815/ijisa.2018.04.03 